\title{
Children hospitalized for COVID-19 during the first winter of the pandemic in Buenos Aires, Argentina
}

\author{
Silvina Raiden ${ }^{1}$, Héctor Cairoli ${ }^{1}$, Javier Potasnik${ }^{1}$, Sandra Di Lalla ${ }^{1}$, María J. Chiolo ${ }^{1}$, Fernando Torres², \\ Paula Domínguez ${ }^{2}$, and Fernando Ferrero ${ }^{1 *}$ \\ ${ }^{1}$ Departamento de Medicina; ${ }^{2}$ Docencia e Investigación. Hospital General de Niños Pedro de Elizalde, Buenos Aires, Argentina
}

\begin{abstract}
Background: Although there are reports on COVID-19 in pediatrics, the characteristics of the population of each country, its health systems, and how the pandemic was addressed could give the disease distinctive features worldwide. We aimed to describe the characteristics of patients hospitalized for COVID-19 in a tertiary pediatric hospital in the City of Buenos Aires, Argentina. Methods: We conducted a descriptive study, including all patients hospitalized for COVID-19 from 04/26/2020 to 10/31/2020 in a tertiary pediatric hospital. We described the demographic, clinical, and epidemiological characteristics of the patients. Results: During the period studied, 578 patients were hospitalized with COVID-19. The median age was 4.2 years, and $83 \%$ reported close contact with a confirmed COVID-19 case. Regarding severity, $30.8 \%$ were asymptomatic, and $60.4 \%$ showed mild, $7.4 \%$ moderate, and $1.4 \%$ severe symptoms. Among symptomatic patients, fever was the most frequent symptom, followed by sore throat and cough. Conclusions: We reported 578 cases of children and adolescents hospitalized with COVID-19, of which the majority showed mild or asymptomatic disease.
\end{abstract}

Keywords: Coronavirus infection. COVID-19. Pneumonia. Hospitalization. Children.

\section{Niños hospitalizados por COVID-19 durante el primer invierno de la pandemia en Buenos Aires, Argentina}

\section{Resumen}

Introducción: Si bien existen reportes sobre COVID-19 en pediatría, es posible que las características de la población de cada país, sus sistemas de salud y cómo enfrentaron la pandemia hayan hecho que la enfermedad mostrara rasgos distintivos a escala global. El objetivo de este trabajo es describir las características de los pacientes hospitalizados por COVID-19 en un hospital pediátrico terciario de la ciudad de Buenos Aires, Argentina. Métodos: Se llevó a cabo un estudio descriptivo que incluyó a todos los pacientes hospitalizados por COVID-19 del 26 de abril al 31 de octubre de 2020 en un hospital pediátrico de tercer nivel. Se describen las características demográficas, clínicas y epidemiológicas de los pacientes. Resultados: Durante el período estudiado fueron hospitalizados 578 pacientes con COVID-19. La mediana de edad fue de 4.2 años y el $83 \%$ reportó antecedentes de contacto cercano con un caso confirmado de COVID-19. En cuanto a la gravedad, el $30.8 \%$ fueron asintomáticos y el $60.4 \%$ mostraron síntomas leves, el $7.4 \%$ moderados y el $1.4 \%$ graves. Entre los pacientes sintomáticos, el síntoma más frecuente fue la fiebre, seguida de odinofagia y tos. Conclusiones: Se reportaron 578 casos de niños y adolescentes hospitalizados con COVID-19, de los cuales la mayoría presentó enfermedad leve o fueron asintomáticos.

Palabras clave: Infección por coronavirus. COVID-19. Neumonía. Hospitalización. Niños.

\section{Correspondence:}

*Fernando Ferrero

E-mail: fferrero@intramed.net
Date of reception: 24-02-2021

Date of acceptance: 15-04-2021 DOI: 10.24875/BMHIM.21000039
Available online: 29-09-2021 Bol Med Hosp Infant Mex. 2021;78(6):501-505 www.bmhim.com 1665-1146/C 2021 Hospital Infantil de México Federico Gómez. Published by Permanyer. This is an open access article under the CC BY-NC-ND license (http://creativecommons.org/licenses/by-nc-nd/4.0/). 


\section{Introduction}

Although the COVID-19 pandemic has caused hundreds of thousands of deaths worldwide, the current information shows that the disease is less severe in the pediatric population ${ }^{1,2}$.

Some studies report that the course of the pandemic could be influenced by each country's characteristics, its health systems, and the way it has dealt with the pandemic $^{3,4}$.

Argentina faced the pandemic in a particular way, including one of the longest lockdowns ${ }^{5}$ and the mandatory hospitalization of affected children ${ }^{6}$. These characteristics could give a distinctive feature to children hospitalized for this disease in Argentina.

We aimed to describe the characteristics of patients hospitalized for COVID-19 in a pediatric tertiary hospital in the City of Buenos Aires.

\section{Methods}

We conducted a retrospective study including all patients hospitalized with COVID-19 in a tertiary pediatric hospital in Buenos Aires, Argentina, from April 26 to October 31, 2020. In addition to patients admitted for COVID-19, all cases requiring hospitalization for other reasons were analyzed. Infection was diagnosed by identification of SARS-CoV-2 in nasopharyngeal secretions by RT-PCR.

The study population included subjects who spontaneously attended our hospital for suspected COVID-19 (symptoms or history of close contacts) ${ }^{7}$ and subjects who were identified by active surveillance in impoverished neighborhoods 8 . Of these neighborhoods, those symptomatic subjects with SARS-CoV-2 identified by $\mathrm{PCR}$, those under 2 years of age, or those older than that age who could not complete isolation at home were hospitalized ${ }^{7}$. We also included patients who required hospitalization for another reason and whose SARSCov-2 infection was identified on admission.

In all cases, we registered demographic characteristics, such as sex, age, place of residence (including whether they lived in an impoverished neighborhood ${ }^{9}$ ), the onset of symptoms on admission, close contact with a confirmed COVID-19 case, presence of any comorbidity, and duration of hospital stay.

Disease severity was established according to Dong et al. ${ }^{10}$; patients with SARS-CoV-2-related multisystem inflammatory syndrome (MIS-C) were considered severe/critical.
The results of laboratory tests (hemoglobin, differential WBC count, platelets, C-reactive protein, and erythrocyte sedimentation rate) were also recorded.

The Ethics Committee of the institution approved the study.

\section{Statistical analysis}

Categorical variables were described by proportions with $95 \%$ confidence intervals $(95 \% \mathrm{Cl})$ and continuous variables by the mean and standard deviation or median and interquartile range (IQR), according to the distribution (Kolmogorov-Smirnov test). For the analysis, the IBM SSPS Statistics 20.0 software was used.

\section{Results}

During the period studied, 578 children and adolescents were hospitalized for COVID-19. Some characteristics of 191 of these patients were mentioned in a preliminary report at the beginning of the pandemic ${ }^{9}$. Here, we described the characteristics of all patients hospitalized for COVID-19 during the entire cold season (May-October), including laboratory data.

The number of hospitalizations ranged from 2 to 42 per week (median = 30.5; IQR: 21.7-35.7) (Figure 1). The median age was 4.2 years (IQR: 0.7-11.2), and $54.5 \%$ of the patients were male. A total of $67.3 \%$ were residents within the hospital's jurisdiction (City of Buenos Aires), and, of these, $23.1 \%$ lived in a low-income neighborhood.

Also, $83 \%$ had a history of close contact with a confirmed case of COVID-19. The onset of symptoms before admission was one day (IQR: 1-3), and 35.3\% had a previous or concomitant diagnosis of another disease, with asthma being the most frequent $(n=49)$ (Table 1).

Disease severity was assessed, and the following results were observed: $30.8 \%$ were considered asymptomatic, $60.4 \%$ mild, $7.4 \%$ moderate, and $1.4 \%$ severe. Of the six severe cases, only one required assisted ventilation, and two had SARS-CoV-2-related MIS-C. Other six MIS-C cases were admitted to the hospital, but SARS-CoV-2 tests were negative at that time. In addition, the most frequent initial symptom was fever, followed by sore throat and cough (Table 2).

Regarding laboratory tests results, we found that $9.4 \%$ showed lymphopenia (differential lymphocyte count $<20 \%$ ) and $23.8 \%$ had elevated C-reactive protein values (C-reactive protein $>10 \mathrm{mg} / \mathrm{dL}$ ) in $100 \%$ of severe cases and $10 \%$ among asymptomatic 


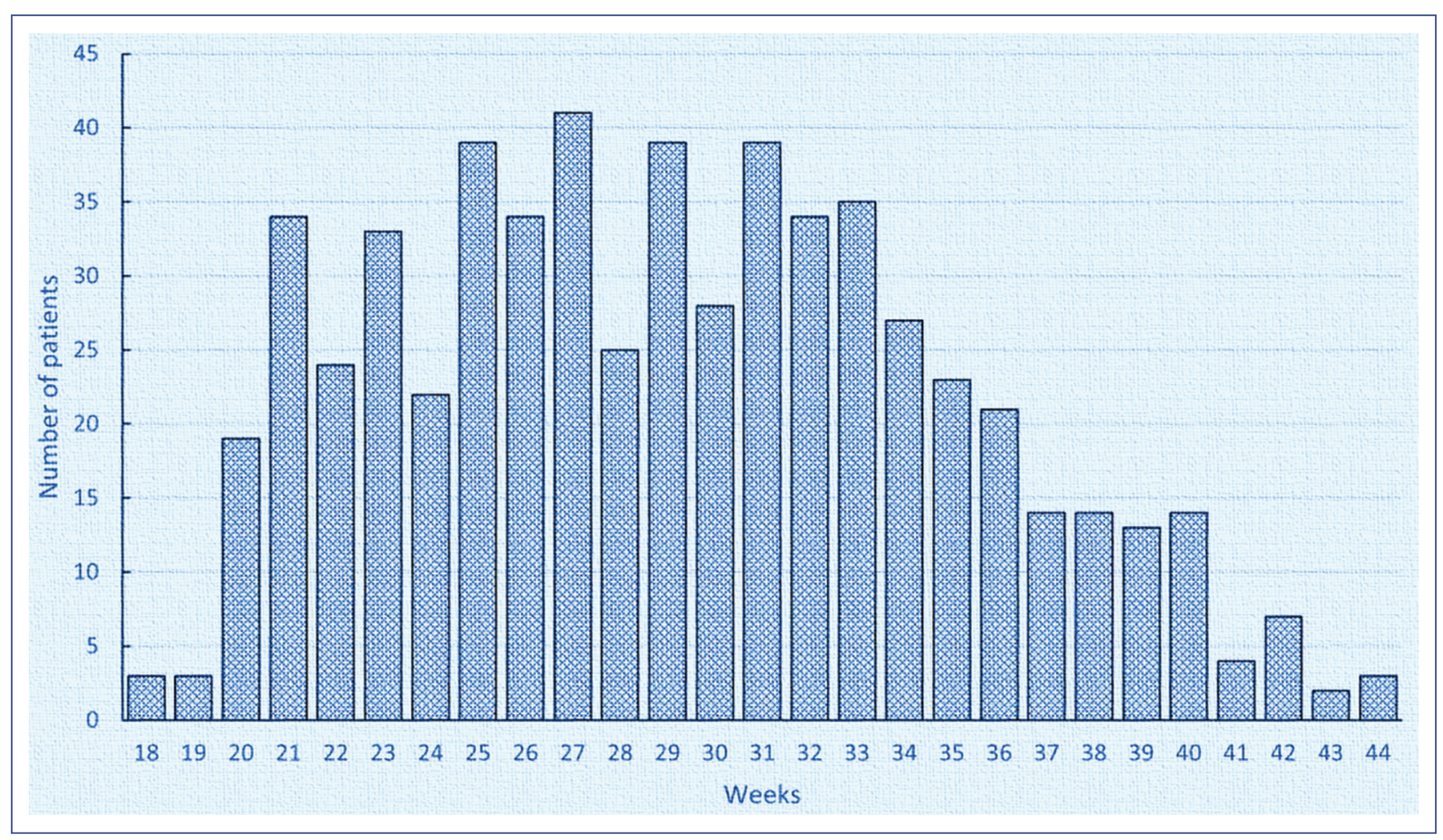

Figure 1. Pediatric hospitalizations for COVID-19 according to the epidemiological weeks.

cases (Table 3). The median length of stay was 6 days (IQR: 2.2-9).

At the time of this report, only one COVID-19 patient died of causes other than the disease, as he had been in end-of-life care for more than a month before infection. All patients were discharged without complications (with phone follow-up), except those whose comorbidity prevented this.

Patients with MIS-C were treated according to local guidelines (including assisted ventilation, systemic corticosteroids, and vasoactive drugs, when necessary $)^{11}$. According to local guidelines, patients received supportive measures and no disease-specific or experimental treatments ${ }^{12}$. When appropriate, patients also received treatment for their comorbidities.

\section{Discussion}

The present study reinforces the idea that the manifestations of COVID-19 in pediatrics, in general, are mild. It also supports some characteristics of the disease observed in Argentina, suggested by our group in a previous report ${ }^{13}$.

Although the age structure (for example, Argentina has twice as many children under 15 years of age as Italy, the first Western country affected by the pandemic) and the social behavior of the different populations may influence the differences observed ${ }^{14,15}$, how local health authorities dealt with the pandemic has generated some particular features in our patients: Buenos Aires reported more pediatric cases than other countries, and we found a higher proportion of asymptomatic patients and with mild symptomatology among those hospitalized.

The City of Buenos Aires adopted a test-and-trace policy. This program was carried out more strongly in poor neighborhoods with a younger population ${ }^{8}$. Mandatory hospitalization of still asymptomatic infants was also established ${ }^{6,7}$. Furthermore, asymptomatic children and adolescents who were unable to comply with out-of-hospital isolation at home were hospitalized during the isolation period ${ }^{16}$.

Up to October 31, 2020, the City of Buenos Aires reported 147,363 cases of COVID-19, of which $12.1 \%$ were children and adolescents ${ }^{17}$. This proportion was substantially higher than initially reported in China $(2.1 \%)^{18}$ and Italy ${ }^{19}$, but closer to that most recently reported in the United States $(9 \%)^{20}$.

We found a high proportion of asymptomatic patients (30.8\%), higher than that reported by Götzinger et al. in Europe in 582 children with SARS-CoV-2 infection (16\%) ${ }^{21}$. Despite this high number of asymptomatic children, the 
Table 1. Comorbidities in pediatric patients hospitalized for COVID-19 $(n=204 / 578)$

\begin{tabular}{|l|l|}
\hline Disease & n \\
\hline Asthma & 49 \\
\hline $\begin{array}{l}\text { Surgical conditions (appendicitis, } \\
\text { testicular torsion, hernias) }\end{array}$ & 12 \\
\hline Seizures & 11 \\
\hline Non-progressive chronic encephalopathy & 11 \\
\hline Genetic disorders & 9 \\
\hline Tumors & 8 \\
\hline Tuberculosis & 8 \\
\hline Other infections (otitis, cellulitis, hepatitis) & 8 \\
\hline Urinary tract infection & 7 \\
\hline Obesity & 5 \\
\hline Diabetes mellitus & 5 \\
\hline Thrombocytopenic purpura & 5 \\
\hline Chronic kidney disease & 5 \\
\hline Chronic lung disease/ & 4 \\
\hline Bronchopulmonary dysplasia & 2 \\
\hline Congenital heart disease & 2 \\
\hline Hemolytic-uremic syndrome & 48 \\
\hline Hematologic disease (spherocytosis, hemophilia) & 2 \\
\hline Human immunodeficiency virus & \\
\hline Other & \\
\hline
\end{tabular}

Table 2. Initial symptoms of patients hospitalized for COVID-19 $(n=400)$

\begin{tabular}{|l|l|l|}
\hline Symptom & $\mathbf{n}$ & $\%$ \\
\hline Fever & 207 & 51.7 \\
\hline Sore throat & 49 & 12.2 \\
\hline Cough & 40 & 10 \\
\hline Rhinorrhea & 39 & 9.7 \\
\hline Headache & 37 & 9.2 \\
\hline Diarrhea/vomiting & 35 & 8.7 \\
\hline Dyspnea & 17 & 4.2 \\
\hline Abdominal pain & 15 & 3.7 \\
\hline Loss of smell & 13 & 3.2 \\
\hline Rash & 6 & 1.5 \\
\hline Loss of taste & 3 & 0.7 \\
\hline
\end{tabular}

Table 3. Laboratory results of children hospitalized for COVID-19

\begin{tabular}{|l|c|c|}
\hline & Mean & SD \\
\hline Hemoglobin (mg/dL) & 12.5 & 1.4 \\
\hline White blood cells count $(/ \mathrm{mL})$ & 8,062 & 3,889 \\
\hline Differential lymphocyte count (\%) & 49 & 20 \\
\hline Neutrophil differential count $(\%)$ & 39 & 20 \\
\hline Platelet count $(/ \mathrm{mL})$ & 289,544 & 106,073 \\
\hline Erythrocyte sedimentation rate $(\mathrm{mm} / \mathrm{h})$ & 13 & 12 \\
\hline C-reactive protein $(\mathrm{mg} / \mathrm{dL})$ & 14 & 38 \\
\hline
\end{tabular}

proportion of those with any comorbidity (35.3\%) was similar to other series ${ }^{22,23}$. Our findings are probably related to the test-and-trace and institutional isolation policies adopted by the local health authorities.

As reported ${ }^{24}$, we also found a higher proportion of subjects with comorbidities among patients with moderate and severe symptomatology than those with mild disease or asymptomatic. However, this result should be assessed with caution due to our series's low proportion of patients with moderate and severe disease (8.8\%).

We found only $7.4 \%$ of moderate and $1.4 \%$ severe cases. Dong et al. in China reported $5.9 \%$ severe and critical cases ${ }^{10}$, and Tagarro et al. in Spain reported that $9.7 \%$ of the cases in this series were severe ${ }^{25}$. Although a report from the United States showed that $32 \%$ of hospitalized pediatric patients with COVID-19 were admitted to a PICU, the limited mean length of stay (2 days) and the limited proportion of subjects requiring assisted ventilation (5.8\%) suggest that the admission criteria in this series were broader ${ }^{23}$.

The cases of MIS-C (multisystem inflammatory syndrome associated with COVID-19 in children) appeared 4 to 6 weeks after reaching a significant number of cases in our city, as described for the development of this complication ${ }^{26}$.

Finally, we found that $83 \%$ of our patients had close contact with infected people, supporting the idea that children are usually infected from adults ${ }^{27}$.

Our report has limitations that should be mentioned. On the one hand, long-term follow-up of our patients was not carried out, which would have allowed us to identify cases that can be considered "long COVID," although the presence of this condition in children seems to be very infrequent ${ }^{28}$. On the other hand, this study only presents data from a single-center, although 
it is probably the public institution that has hospitalized the most pediatric patients with COVID-19 in our country. Moreover, the inclusion of single-center data shows that in winter with no respiratory syncytial virus (RSV)related hospitalizations, the number of patients hospitalized for COVID-19 is approximately the same as those admitted for RSV disease each year ${ }^{29}$, regardless of whether this is related to non-pharmaceutical interventions used to control the pandemic ${ }^{30}$.

In this study, 578 cases of children and adolescents hospitalized for COVID-19 in Argentina were reported. The majority presented mild or asymptomatic disease, supporting the idea that the management of pediatric patients with COVID-19 represents more of an organizational challenge than a specific clinical task ${ }^{31}$.

\section{Ethical disclosures}

Protection of human and animal subjects. The authors declare that no experiments were performed on humans or animals for this study.

Confidentiality of data. The authors declare that they have followed the protocols of their work center on the publication of patient data.

Right to privacy and informed consent. The authors have obtained the written informed consent of the patients or subjects mentioned in the article. The corresponding author has this document.

\section{Conflicts of interest}

The authors declare no conflict of interest.

\section{Funding}

None.

\section{References}

1. Ludvigsson JF. Systematic review of COVID-19 in children shows milder cases and a better prognosis than adults. Acta Paediatr. 2020;109:1088-95.

2. Hoang A, Chorath K, Moreira A, Evans M, Burmeister-Morton F, Burmeister $F$, et al. COVID-19 in 7780 pediatric patients: a systematic review. EClinicalMedicine. 2020;24:100433.

3. Smit AJ, Fitchett JM, Engelbrecht FA, Scholes RJ, Dzhivhuho G, Sweijd NA. Winter is coming: a southern hemisphere perspective of the environmental drivers of SARS-CoV-2 and the potential seasonality of COVID-19. Int J Environ Res Public Health. 2020;17:5634.

4. Tanne JH, Hayasaki E, Zastrow M, Pulla P, Smith P, Rada AG. COVID-19: how doctors and healthcare systems are tackling coronavirus worldwide. BMJ. 2020;368:m1090.

5. Larrosa JMC. SARS-CoV-2 in Argentina: Lockdown, mobility, and contagion. J Med Virol. 2021;93:2252-61.

6. Gobierno de la Ciudad Autónoma de Buenos Aires. Protocolo de manejo frente a casos sospechosos y confirmados de coronavirus (COVID 19) en pediatría. Versión 3 (8 de mayo de 2020). pp. 6. Buenos Aires: Ministerio de Salud, Gobierno de la Ciudad Autónoma de Buenos Aires: 2020. Available from: https://www.buenosaires.gob.ar/sites/gcaba/files/p. pediatria8.05.pdf.
7. Gobierno de la Ciudad Autónoma de Buenos Aires. Protocolo de manejo frente a casos sospechosos y confirmados de coronavirus (COVID 19). Versión 30 (7 de junio de 2020). Buenos Aires: Ministerio de Salud, Gobierno de la Ciudad Autónoma de Buenos Aires; pp. 6.

8. Figar S, Pagotto V, Luna L, Salto J, Wagner-Manslau M, Mistchenko AS, et al. Community-level SARS-CoV-2 seroprevalence survey in urban slum dwellers of Buenos Aires City, Argentina: a participatory research. medRxiv; 2020. Available from: https://www.medrxiv.org/content/10.110 1/2020.07.14.20153858v2.

9. Registro Nacional de Barrios Populares. Argentina: Ministerio de Desarrollo Territorial y Hábitat; 2020. Available from: https://www.argentina. gob.ar/habitat/renabap.

10. Dong Y, Mo X, Hu Y, Qi X, Jiang F, Jiang Z, et al. Epidemiology of COVID-19 among children in China. Pediatrics. 2020;145:e20200702.

11. Gobierno de Argentina. Manejo inicial del síndrome inflamatorio multisistémico en niños y adolescentes relacionados temporalmente al Covid-19 (SIM-C). Argentina: Ministerio de Salud; 2020. Available from: https:// bancos.salud.gob.ar/recurso/manejo-inicial-del-sindrome-inflamatorio-multisistemico-en-ninos-y-adolescentes.

12. Gobierno de Argentina. Vigilancia, diagnóstico y manejo institucional de casos en pediatría. Buenos Aires: Ministerio de Salud; 2021. Available from: https://www.argentina.gob.ar/salud/coronavirus-COVID-19/casos-pediatria.

13. Cairoli H, Raiden S, Chiolo MJ, Di Lalla S, Ferrero F. Patients assisted at the Department of Medicine of a pediatric hospital at the beginning of the COVID-19 pandemic in Buenos Aires, Argentina. Arch Argent Pediatr. 2020;118:418-26.

14. Natale F, Ghio D, Tarchi D, Goujon D, Conte A. COVID-19 cases and case fatality rate by age. European Comission: 2020. Available from: knowledge4policy.ec.europa.eu

15. Dowd JB, Andriano L, Brazel DM, Rotondi V, Block P, Ding X, et al. Demographic science aids in understanding the spread and fatality rates of COVID-19. Proc Natl Acad Sci USA. 2020:117:9696-8.

16. Gobierno de la Ciudad Autónoma de Buenos Aires. Protocolo de manejo frente a casos sospechosos y confirmados de coronavirus (COVID 19). Versión 32 (19 de junio de 2020). Buenos Aires: Ministerio de Salud, Gobierno de la Ciudad Autónoma de Buenos Aires; pp. 16.

17. Gobierno de la Ciudad Autónoma de Buenos Aires. Actualización de los casos de coronavirus en la Ciudad. Buenos Aires: Ministerio de Salud, Gobierno de la Ciudad Autónoma de Buenos Aires; 2020. Available from: https://www.buenosaires.gob.ar/coronavirus/noticias/actualizacion-de-los-casos-de-coronavirus-en-la-ciudad-buenos-aires.

18. The Novel Coronavirus Pneumonia Emergency Response Epidemiology Team. [The epidemiological characteristics of an outbreak of 2019 novel coronavirus diseases (COVID-19) in China]. China CDC Weekly. 2020;2:113-22.

19. Livingston E, Bucher K. Coronavirus disease 2019 (COVID-19) in Italy. JAMA. 2020;323:1335.

20. Centers for Disease Control and Prevention. CDC COVID Data Tracker. Demographic Trends of COVID-19 cases and deaths in the US reported to CDC. Atlanta, GA: US Department of Health and Human Services, CDC; 2020.

21. Götzinger $F$, Santiago-García $B$, Noguera-Julián $A$, Lanaspa $M$, Lancella L, Calò Carducci FI, et al. COVID-19 in children and adolescents in Europe: a multinational, multicentre cohort study. Lancet Child Adolesc Health. 2020;4:653-61.

22. Rao S, Gavali V, Prabhu SS, Mathur R, Dabre LR, Prabhu SB, et al. Outcome of children admitted with SARS-CoV-2 infection: experiences from a pediatric public hospital. Indian Pediatr. 2021;58:358-62.

23. Kim L, Whitaker M, O'Halloran A, Kambhampati A, Chai SJ, Reingold A, et al. Hospitalization rates and characteristics of children aged $<18$ years hospitalized with laboratory-confirmed COVID-19-COVID-NET, 14 States, March 1-July 25, 2020. MMWR Morb Mortal Wkly Rep. 2020;69:1081-8.

24. Graff K, Smith C, Silveira L, Jung S, Curran-Hays S, Jarjour J, et al. Risk factors for severe COVID-19 in children. Pediatr Infect Dis J. 2021;40:e137-45.

25. Tagarro A, Epalza C, Santos M, Sanz-Santaeufemia FJ, Otheo E, Moraleda C, et al. Screening and severity of coronavirus disease 2019 (COVID-19) in children in Madrid, Spain. JAMA Pediatr. 2020;e201346.

26. Jiang L, Tang K, Levin M, Irfan O, Morris SK, Wilson K, et al. COVID-19 and multisystem inflammatory syndrome in children and adolescents. Lancet Infect Dis. 2020;20:e276-e288.

27. Munro APS, Faust SN. Children are not COVID-19 super spreaders: time to go back to school. Arch Dis Child. 2020;105:618-9.

28. Ludvigsson JF. Case report and systematic review suggest that children may experience similar long-term effects to adults after clinical COVID-19. Acta Paediatr. 2021;110:914-21.

29. Ferrero F, Torres F, Abrutzky R, Ossorio MF, Marcos A, Ferrario C et al. Seasonality of respiratory syncytial virus in Buenos Aires. Relationship with global climate change. Arch Argent Pediatr. 2016;114:52-5.

30. Baker RE, Park SW, Yang W, Vecchi GA, Metcalf CJE, Grenfell BT. The impact of COVID-19 non-pharmaceutical interventions on the future dynamics of endemic infections. Proc Natl Acad Sci USA. 2020;117:30547-53.

31. Parri N, Lenge M, Cantoni B, Arrighini A, Romanengo M, Urbino A, et al. COVID-19 in 17 Italian pediatric emergency departments. Pediatrics. 2020;146:e20201235. 